\title{
Urease Activity in Soybean Meal Products ${ }^{1}$
}

\author{
ALLAN K. SMITH, PAUL A. BELTER, ${ }^{2}$ and ROBERT L. ANDERSON, ${ }^{3}$ \\ Northern Utilization Research Branch," Peoria, lllinois
}

$\mathrm{T}$ HE PROCESSING OF soxbeans for oil and meal by solvent extraction includes the important operation of steaming or "toasting" $(1,6)$ of the meal for development of optimum nutritional value. The toasting operation follows removal of the hydrocarbon solvent which usually involves the use of steam. Because too much moist heat is detrimental to the nutritive value of the protein, the time and temperature of toasting must be controlled within optimum limits.

Many test methods for control of toasting have been proposed (4), but the two which have been used most are 1) the modified Caskey-Knapp $(2,3)$, an assay for urease, and 2) the nitrogen-solubility method, a measurement of the water-soluble nitrogen compounds (8), often referred to as the nitrogen-solubility index or N'SI value. The modified Caskey-Knapp (2) is a method which measures a change in the $\mathrm{pH}$, for a given reaction time, of a weakly buffered system of soybean oil meal and urea. Recently Croston, Smith, and Cowan (4) proposed a method based on an increase of the electrical conductivity of a soybean oil meal system similar in composition to that used in the Caskey-Knapp method. The modified Caskey-Knapp and electrical conductivity methods are useful only for toasted meals which are produced for use in feeds, in which an estimated 99.5 to $99.95 \%$ of the urease activity has been destroyed, and in which the changes in $\mathrm{pH}$ or conductivity are very small.

The increasing utilization of soybean meal in special food products and for industrial purposes has created a need for another analytical control method. These meals prepared for specialty uses receive much less steam treatment than feed meals and have a high urease activity. This report deals primarily with the development of an assay method for urease in these soybean meals of high activity. Included in the investigation are data on the rate of urease inactivation with steam treatment at atmospheric pressure, a comparison of urease activity in several varieties of soybeans, the activity of immature and frost-damaged beans, and several factors affecting the precision of the assay method.

In a 1941 study of the activity of a crystalline urease system Sizer and Tytell (7) showed that activity is modified by the oxidation-reduction potential of a system as controlled by added oxidizing or reducing compounds and that a certain optimum potential favors a maximum activity value.

Using an assay method in which the reaction was carried out at $20^{\circ} \mathrm{C}$., Hofstee (5) demonstrated in 1949 that, when crystalline urease or a water extract of the jack bean was stored under refrigeration temperatures or in the frozen state, the assay results were very low. However if the same urease samples, after storage at reduced temperature, were heated to $60^{\circ} \mathrm{C}$. for $5 \mathrm{~min}$., the assay results on a given sample were uniformly high. Assay values for heat-treated samples were as much as five times those without the treatment.

\footnotetext{
1 Presented at the meeting of the American Oil Chemists' Society, Houston, Tex., Apr. 23-25, 1956.

2 Present address: University of Michigan, Ann Arbor.

3 In military service

4 One of the Branches of the Agricultural Research Service, U. S Department of Agriculture.
}

Neither the investigations of Sizer and Tytell nor those of Hofstee included data on soybean meal. Therefore our investigations were made on the effect of adding oxidizing and reducing agents and on preheat treatment of the meal as well as other factors affecting the assay of urease in soybeans.

\section{Method}

The assay method used for this determination was a "continuous titration" of ammonia method mentioned previously by Croston et al. (4). 'This method maintains the $\mathrm{pH}$ of the urease-urea reaction at its optimum activity of about 6.8 during the reaction period to prevent a decrease in urease activity with increasing alkalinity. This was accomplished by adding standard hydrochloric acid from a burette and using bromothymol blue or a $\mathrm{pH}$ meter to indicate the desired end-point. In routine work the time used in titration can be largely eliminated by use of auto. matic titrating equipment. Unless otherwise indicated, all samples were prepared by grinding the dehulled and defatted flakes in a hammer mill to pass an 80 mesh screen. Size of the sample was reduced from $200 \mathrm{mg}$. used by Croston for feed meals to $20 \mathrm{mg}$. This small sample was shown to be representative by a series of check determinations made on different days. All reactions were carried out in a constant temperature bath at $40^{\circ} \mathrm{C}$. except as indicated.

The reagents used were (1) $0.1 \mathrm{NHCl}$, (2) $0.1 \mathrm{~N}$ $\mathrm{NaOH}$, (3) phosphate buffer of $\mathrm{pH} 6.8$ made up of 0.025 mole of $\mathrm{K}_{2} \mathrm{HPO}_{4}, 0.025$ mole $\mathrm{KH}_{2} \mathrm{PO}_{4}$, and $0.8 \mathrm{~g}$. of glutathione per liter, and (4) buffered urea solution made up daily by dissolving $6 \mathrm{~g}$. C.P. urea in $100 \mathrm{ml}$. of buffer solution number (3) without the glutathione.

Procedure. Assays were carried out in beakers in a constant temperature bath at $40^{\circ} \mathrm{C}$. For each determination of highly active meal a $20-\mathrm{mg}$. sample (unless otherwise indicated) was added to $5 \mathrm{ml}$. of the buffer solution (3) containing the glutathione and was allowed to stand for $30 \mathrm{~min}$. in the $40^{\circ} \mathrm{C}$. bath : $5 \mathrm{ml}$. of the buffered urea solution (4) were then added to start the reaction. The $\mathrm{pH}$ of the reaction was maintained at approximately 6.8 by slowly adding $0.1 \mathrm{~N} \mathrm{HCl}$ and using bromthymol blue in its green color range to indicate the desired end-point. At the end of 30 min. the reaction was terminated by rapidly adding additional $0.1 \mathrm{~N} \mathrm{HCl}$ to a total of $10 \mathrm{ml}$., or more, as required for very highly active meals. The system was then titrated with $0.1 \mathrm{~N} \mathrm{NaOH}$ to $\mathrm{pH} 4.7$. A pH meter indicated the end-point. A control was run parallel with each sample. For the control the urease was inactivated by adding the hydrochloric acid to the sample before adding buffers (3) and (4). The difference between the control and sample in milliliters of $0.1 N \mathrm{HCl}$ or its ammonia equivalent was taken as the urease activity of the meal.

The principal differences between this procedure and that described by Croston et al. are the soaking of the sample for $30 \mathrm{~min}$. at $40^{\circ} \mathrm{C}$. and the use of a reducing agent. The need for these modifications as well as other factors affecting the assay of urease activity 
in untoasted and lightly toasted meals is described in the following section.

\section{Factors Affecting Urease Activity}

Soaking Time and Effect of Mild Steam Treatment. The effects of soaking raw meal and lightly steamed meal in a $\mathrm{pH} 6.8$ phosphate buffer (without redueing agent) for various periods of time are shown in Figure 1. The solid lines are for raw or unsteamed meal,

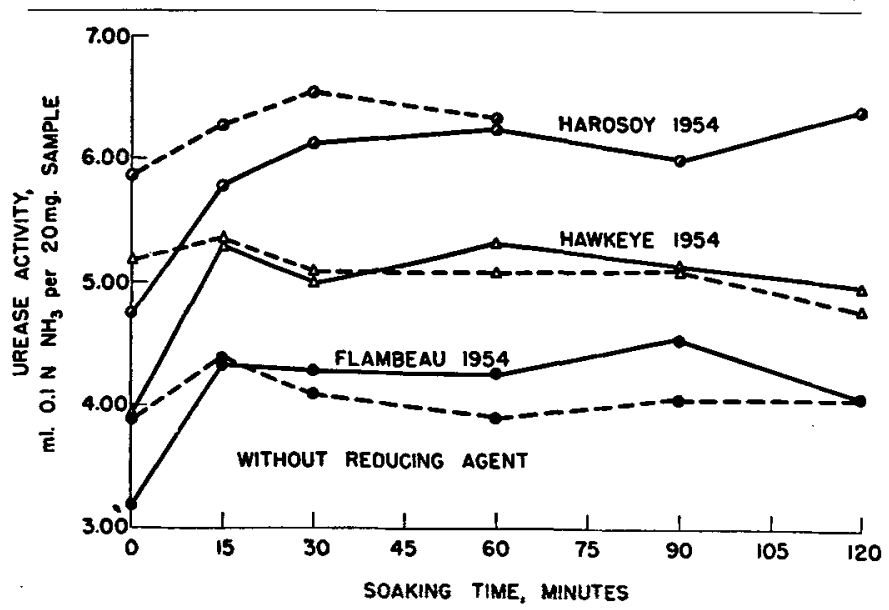

FIG. 1. Effect on urease activity of time of soaking of raw and of lightly steamed soybean meals at $40^{\circ} \mathrm{C}$. in $\mathrm{pH} 6.8$ phosphate buffer for various periods. Solid lines are for raw meal, and broken lines are for very lightly steamed meal. No reducing agent present in these assays.

and the broken lines are for the same meal treated in an autoclave with live steam for 5 min.; the steam treatment started with a cold autoclave. The differences in results for raw and lightly steamed meals at zero soaking time show an effect similar to but less than those found by Hofstee in his pre-heat treatment of crystalline urease and jack bean extracts. These results also show that soaking the raw meal for about 30 min. at $40^{\circ} \mathrm{C}$. increases the activity to about the same value as for the lightly steamed meal.

Reducing Agents. The effect of glutathione on the assay of laboratory samples of raw meals prepared from several varieties of soybeans is shown in Figure 2. These assays were made by adding increasing amounts of glutathione to the samples buffered to

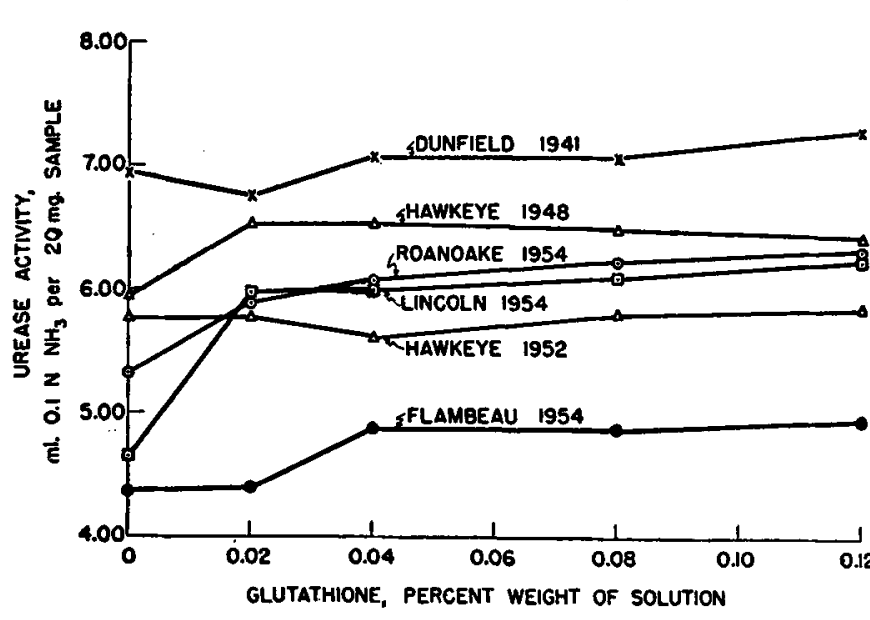

FIg. 2. Effect of various concentrations of glutathione (0 to $0.12 \%$ on solution volume) on urease activity of soybean meal for several varieties of soybeans.
pH 6.8 and comparing the results with samples having no glutathione. All samples were presoaked for 30 min. at $40^{\circ} \mathrm{C}$.

The results with glutathione are not uniform; for most samples the glutathione increased the assay values whereas for others the results were unchanged. The effects of cysteine and hydrogen peroxide also were investigated. The cysteine at double the concentration of glutathione gave about the same general type of results whereas the values obtained with peroxide were low, indicating an inactivating effect. The effect of peroxide was also lacking in uniformity.

Although the magnitude of the effects of glutathione and of hydrogen peroxide on activity were nonuniform, the general trend was for reducing agents to increase the assay values and for oxidizing agents to decrease them. Since enzyme activity is generally measured at optimum conditions, the use of a reducing agent (glutathione) and the 30-min. presoaking period were made a part of the assay procedure. In the adopted procedure the concentration of glutathione was $0.08 \%$ by weight during the 30 -min. presoaking period and $0.04 \%$ during the reaction period. In subsequent experiments the effect of glutathione on the assay of toasted meals was not detectable. However its use is recommended for all highly active meals since the amount of toasting required before reducing agents lose their activating effect was not determined. Toasting may be expected to increase the number of exposed sulfhydryl groups of the protein and lessen the need for reducing agents.

Our results, like those obtained by Hofstee and by Sizer and Tytell on erystalline urease and extracts of jack bean, show that soaking the soybean meal at an elevated temperature prior to the assay as well as the use of a reducing agent are important factors in obtaining optimum and uniform results. To determine whether the $40^{\circ} \mathrm{C},-30$-min. treatment is adequate. a comparison was made with the 5- and $10-\mathrm{min}$. soaking treatments at the $60^{\circ}$ temperature used by Hofstee. Table I shows our urease values for three varieties of

TABLE I

Effect of Time and Temperature of Presoaking and of Glutathione on Urease Aetivity. All Assays at $40^{\circ} \mathrm{O}$. for $30 \mathrm{Min}$.

\begin{tabular}{|c|c|c|c|c|c|}
\hline \multirow{3}{*}{$\underset{\text { No. }}{\text { Sample }}$} & \multirow{3}{*}{ Variety } & \multirow{3}{*}{$\begin{array}{l}\text { Added } \\
\text { glutathione } \\
\text { conc. wt. }\end{array}$} & \multicolumn{3}{|c|}{ Assay value of meals } \\
\hline & & & \multicolumn{3}{|c|}{ Treatment of meals } \\
\hline & & & $\begin{array}{l}60^{\circ} \mathrm{C} \text {. for } \\
5 \mathrm{~min} .\end{array}$ & $\begin{array}{l}60^{\circ} \mathrm{C} \text {. for } \\
10 \mathrm{~min} .\end{array}$ & $\begin{array}{l}40^{\circ} \mathrm{O} \text {. for } \\
30 \mathrm{~min} \text {. }\end{array}$ \\
\hline & & & \multicolumn{3}{|c|}{$0.1 \mathrm{~N} \mathrm{NH}_{3} / 20 \mathrm{mg}$. of sample } \\
\hline 10165 & $\begin{array}{c}\text { Hawkeye } \\
1952\end{array}$ & $\begin{array}{c}\% \\
0.00\end{array}$ & $\begin{array}{l}m l . \\
5.4\end{array}$ & $\begin{array}{l}m l . \\
5.5\end{array}$ & $\begin{array}{l}m l \\
5.8\end{array}$ \\
\hline 2326 & $\begin{array}{c}\text { Dunfield } \\
\mathbf{1 9 4 1}\end{array}$ & 0.00 & 6.4 & 6.4 & 7.0 \\
\hline 11503 & $\underset{\mathbf{1 9 5 4}}{\text { Harosoy }}$ & 0.00 & 6.6 & 6.6 & 6.6 \\
\hline $\begin{array}{r}10165 \\
2326 \\
11503\end{array}$ & $\begin{array}{l}\text { Hawkeye } \\
\text { Dunfield } \\
\text { Harosoy }\end{array}$ & $\begin{array}{l}0.08 \\
0.08 \\
0.08\end{array}$ & $\begin{array}{l}5.7 \\
6.8 \\
7.1\end{array}$ & $\begin{array}{l}\mathbf{5 . 8} \\
6.8 \\
7.2\end{array}$ & $\begin{array}{l}5.8 \\
7.1 \\
7.3\end{array}$ \\
\hline
\end{tabular}

soybean meal. The comparisons were made with and without glutathione in the buffer solution used in the presoaking period. The assays for all samples were made at $40^{\circ}$ for $30 \mathrm{~min}$. The data show that glutathione increases the assay values for all three meals treated at $60^{\circ} \mathrm{C}$. but for only one meal treated at $40^{\circ} \mathrm{C}$. In comparing the three methods of pretreatment, the $40^{\circ} \mathrm{C},-30$-min. method gives values equal to or somewhat higher than the $60^{\circ} \mathrm{C}$. treatment. These experiments further confirm that a reducing agent 
and presoaking period are essential for optimum assay values and that the $40^{\circ} \mathrm{C},-30$-min. treatment is the most effective.

Effect of Waring Blendor. A decrease in the 30-min. soaking period would be desirable for a routine assay. An attempt was made to obtain the same results by treatment of the sample in a Waring Blendor ${ }^{5}$ for $11 / 2$ min. The Blendor treatment, made without a reducing agent in the buffer, had an inactivating effect on the urease and caused a decrease of more than $50 \%$ in the assay values. Use of glutathione in the sample during treatment in the Blendor reduced the rate of inactivation but did not completely inhibit the effect. The inactivation of urease by the Blendor appeared to be an air-oxidizing effeet accelerated by the cavitating action of the Blendor and is further confirmation of the need to control the oxidation-reduction potential of the system during the assay.

Effect of Autoclave Treatment on Disappearance of Urease. Table II and Figure 3 show, for several

\begin{tabular}{|c|c|c|c|c|c|c|c|}
\hline \multicolumn{8}{|c|}{$\begin{array}{l}\text { Effect of Increasing Periods of Heat Treatment in Autoclave on } \\
\text { Orease Activity of Soybean Meal, Expressed in Milliliters } \\
\text { of } 0.1 \mathrm{~N} \text { Ammonia. Note the Increase in Size of Sample } \\
\text { for 15- and 30-Min. Treatments }\end{array}$} \\
\hline \multirow{4}{*}{ Sample No. } & \multicolumn{7}{|c|}{ Time in autoclave, $\min$. } \\
\hline & 0 & 5 & & 10 & & 15 & 30 \\
\hline & \multicolumn{7}{|c|}{ Sample size, in $\mathrm{mg}$. } \\
\hline & 20 & 20 & 20 & 20 & 20 & 100 & 200 \\
\hline 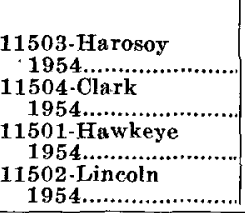 & $\begin{array}{l}\mathrm{ml} \cdot \mathrm{b} \\
7.4 \\
5.6 \\
5.4 \\
5.2\end{array}$ & $\begin{array}{l}\mathrm{ml.b} \\
6.4 \\
3.8 \\
4.0 \\
4.1\end{array}$ & \begin{tabular}{l|}
$\mathrm{ml.c}$ \\
5.7 \\
3.8 \\
3.6 \\
3.5
\end{tabular} & $\begin{array}{l}\mathrm{ml.} \\
4.7 \\
3.2 \\
3.0 \\
3.2\end{array}$ & \begin{tabular}{r|}
$\mathrm{ml.c}$ \\
4.5 \\
3.1 \\
2.9 \\
2.8
\end{tabular} & $\begin{array}{l}\mathrm{ml}^{\mathrm{b}} \\
1.0 \\
0.3 \\
0.15 \\
0.15\end{array}$ & $\begin{array}{l}\text { mI.c } \\
0.11 \\
0.03 \\
0.08 \\
0.02\end{array}$ \\
\hline \multicolumn{8}{|c|}{$\begin{array}{l}\text { Autoclave at atmospheric pressure. } \\
\text { b One day after treatment in autoclave. } \\
\text { c Seven days after treatment in autoclave. }\end{array}$} \\
\hline
\end{tabular}

varieties of soybean meal, the approximate rate at which urease activity decreases when the meal is heated in an autoclave at atmospheric pressure. In this series of experiments the autoclave was thoroughly heated before introducing the meal, therefore the increase in activity after $5 \mathrm{~min}$., which was noted in Figure 2, is not apparent. The more vigorous steam action in this experiment reduced the urease activity below the point where the heat-activating effect can be observed. The data in Table II are the experimentally determined values calculated to milliliters of $0.1 \mathrm{~N}$ ammonia per $20 \mathrm{mg}$. of sample whereas the urease values in Figure 3 are calculated on a percentage basis with the raw meal of each variety assigned a value of $100 \%$. This latter method of calculation starts all urease values at the same point on the graph, namely $100 \%$, but at the end of 5 and 10 minutes of autoclaving there is a substantial difference in the calculated assay values. However as inactivation increases, the measured values approach each other. It is suggested that the method of using a percentage decrease in urease activity of the meal may have an advantage over using the directly determined values. This method of calculation would require a urease measurement prior to desolventizing as the $100 \%$ value. Before deciding on the advantages of one

\footnotetext{
Mention of trade-named products does not imply that they are endorsed or recommended by the Department of Agriculture over other firms or similar products not mentioned.
}

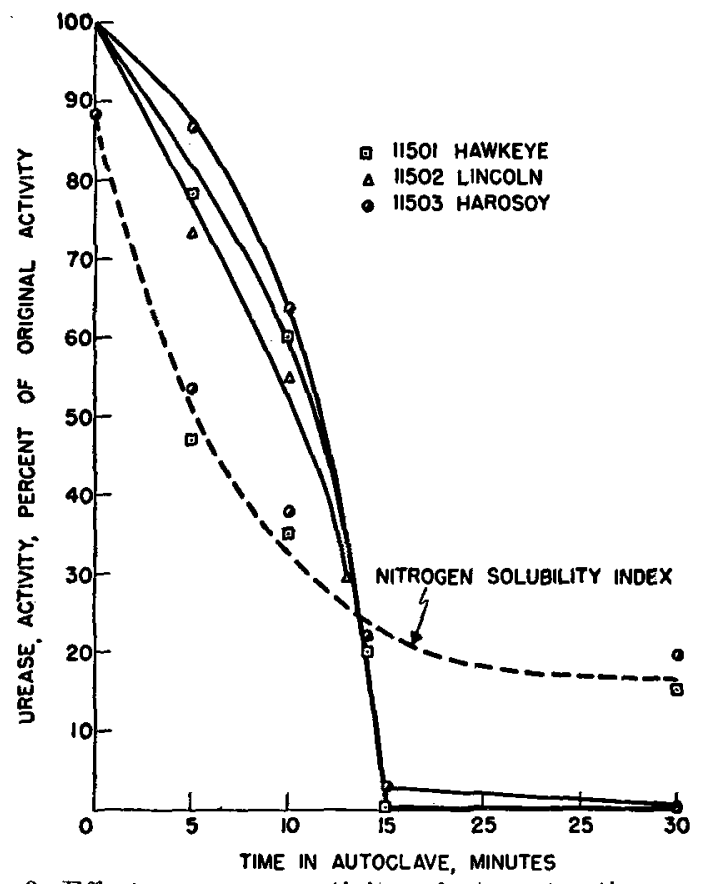

FIG. 3. Effect on urease activity of steam-treating soybean meals in an autoclave at atmospheric pressure in the range of 0 to $30 \mathrm{~min}$. and a comparison with the rate of change of solubility of nitrogenous compounds in water for the same time. The urease values are calculated on a pereentage basis, using the original raw meals as $100 \%$.

method over the other, the variation in urease activity oceurring in plant operation, which might be expected to be less than in a laboratory investigation of this type, should be determined. Beeanse commercial beans are composited to some extent, they may show less variation in urease activity than the selected samples used in this investigation. Figure 3 also shows a comparison of the urease activity method with the nitrogen solubility method of measuring the rate of change in the meal with steam treatment. There is a great dissimilarity in the curves representing the two methods of measurement.

Figure 4 is a graph of the experimentally deter-

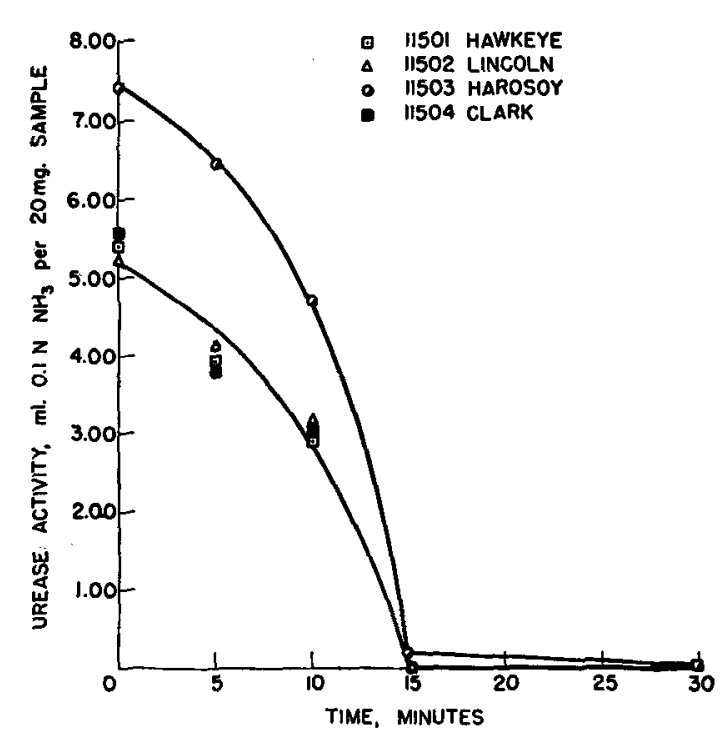

Fig. 4. Urease activity as affected by time of treatment in autoclave at atmospheric pressure for meals obtained from four varieties of soybeans. Results are expressed as $0.1 \mathrm{~N} \mathrm{NH}_{3}$ per $20 \mathrm{mg}$. of meal. 


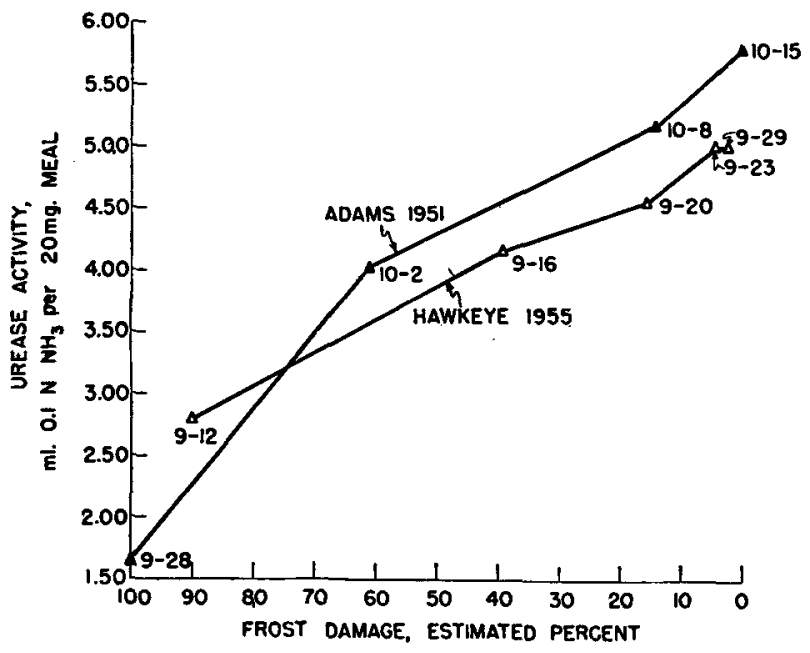

FIG. 5. The urease activity of immature soybeans damaged $(0-100 \%)$ by freezing. Month and day of harvest of each sample is shown on each graph.

mined urease values in terms of $0.1 \mathrm{~N}$ ammonia for the three meals shown in Figure 3 and the additional meal No. 11504. Whereas the values for three of the four meals are reasonably close to each other, the high results of the fourth meal indicate that the unusually high activity of some meals must be considered in using urease activity as a processing control test.

Variation with Variety and Location. In this limited investigation the urease activity of raw meals derived from different varieties of soybeans ranged between 4.5 and $7.6 \mathrm{ml}$. of $0.1 \mathrm{~N}$ ammonia per $20 \mathrm{mg}$. of meal. Stated in other units, $1 \mathrm{mg}$. of meal liberates from 0.38 to $0.65 \mathrm{mg}$. of ammonia from urea. The maximum varietal variation of the samples tested was about $70 \%$. However most values were in a narrower range of 5.5 to $6.5 \mathrm{ml}$., or a variation of about $20 \%$; this is a variation which decreases with increasing heat treatment. Because of the limited number of assays performed and absence of agronomic data there is insufficient information to account for the urease variation. Location appeared to be as much of a factor as variety; for example, Harosoy samples collected at several locations gave activity values of $7.6,6.7,5.5$, and 4.9. This is about the same range found for the different varieties. A more extensive study of variety and location might be expected to show whether soil fertility or climatic conditions are important influences on urease content of the soybean.

Distribution of Urease in Seed Parts. One hundred grams each of Lincoln (11502) and Harosoy beans (11503) were cracked between steel rolls and separated by hand into cotyledons, hulls, and germ. Before removal of the oil the approximate division of the beans into their three parts was $90 \%, 8 \%$, and $2 \%$, respectively. The cotyledon and germ fractions were defatted with hexane, and all three fractions were ground for urease determination. The urease values in ml. of $0.1 \mathrm{~N}$ ammonia per $20-\mathrm{mg}$. samples were as follows:

\begin{tabular}{|c|c|c|c|}
\hline $\mathrm{Hz}$ & Cotyledon & Germ & $\begin{array}{c}\text { Defatted } \\
\text { Whole Meal }\end{array}$ \\
\hline 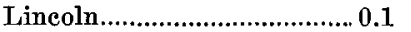 & & 11.2 & 6.0 \\
\hline . & 7.6 & 13.3 & 7.4 \\
\hline
\end{tabular}

These data show that the hulls are very low in urease activity and the germ, on a weight basis, has nearly twice as much activity as the cotyledons. The urease activity contributed by the hulls, germ, and cotyledons to the activity of the whole meal is approximately $0.2 \%, 3.8 \%$, and $96 \%$, respectively. These data indicate that removal of hulls, as is done in some commercial processing, would favor an increased urease value for the combined cotyledon-germ fraction. However since in commercial operation the hulls are incompletely removed and part of the germ usually separates with the hulls, the urease activity of the dehulled meal may not be significantly different from that of the whole meal. In laboratory operation it was noted that, when grinding whole meal in a hammer mill, the hulls resisted grinding and constituted a major portion of the last fraction remaining in or leaving the mill. It was found that this fraction gave 30 to $40 \%$ lower urease values than the "through fraction" and that it was essential to have all of the sample pass through the mill and sereen in order to obtain uniform assays.

Frost Damage and Maturity. Preliminary experiments were made on the urease activity of immature and frost-damaged beans. The frost damage was affected by freezing the immature bean pods in dry ice at the time of harvest. Two series of beans were investigated. The first was an Adams variety which was harvested in 1951 and had been used for oil-color studies at our laboratory; they had been stored at $0^{\circ} \mathrm{C}$. until August, 1955. The second series was Hawkeye beans harvested at various periods in September, 1955. One portion of the 1955 beans was frozen in dry ice at the time of harvest and the other portion was assayed without freezing. All samples were airdried, defatted, and ground for the assay.

Figure 5 shows the urease activity plotted against the percentage of frost damage, which is approximately equal to immaturity. These results show that urease content of soybeans decreases rapidly with increasing frost damage or immaturity. The urease values for the Hawkeye beans assayed without freezing are not shown separately on the graph since they were the same as for the frozen samples thus indicating there is no difference in urease activity between frost-damaged and unfrozen soybeans of the same maturity.

\section{Summary}

A method which uses direct titration of ammonia as a measure of urease activity was modified for use in the assay of raw and of slightly denatured soybean meal. The modifications which were adopted were the use of glutathione, a presoaking of the sample for $30 \mathrm{~min}$. at $40^{\circ} \mathrm{C}$., and making of the assay at $40^{\circ} \mathrm{C}$. Data on the urease activity of several varieties of soybeans, and for immature and frost-damaged soybeans were determined.

\section{REFERENCES}

1. Belter, P. A., and Smith, A. K., J. Am. Oil Chemists' Soc., 29, 170-174 (1952). 2. Bird, H. R., Boucher, R. O., Caskey, C. D. Jr., Hayward, J., W. and Hunter, J. E., J. Asso. Official Agr. Chem., 30, 354-64 (1947), Anal. Ed., 16, 640-641 (1944).

4. Croston, C. B., Smith, A.

ists' Soc., 32, 279-282 (1955). Physiol., 32, 339-349 (1949).

6. Klose, A. A., Hill, Barbara, and Fevold, H. L., Food Technol, 2, 1 (1948).

1 (1948). I. W., and Tytell, A. A., J. Biol. Chem., 138, 631-642

8. Smith, A. K., Belter, P. A., and Johnsen, V. L., J. Am. Oil Chemists' Soc., 29, 309-312 (1952).

[Received March 19, 1956] 